\title{
АКТУАЛЬНІ ПИТАННЯ ВИКЛАДАННЯ ОНКОЛОГІї ДЛЯ СТУДЕНТІВ МЕДИЧНИХ ВУЗІВ ТА ФОРМУВАННЯ КЛІНІЧНОГО МИСЛЕННЯ У МАЙБУТНІХ ЛІКАРІВ
}

\author{
А. П. Ковальчук \\ Вінницький національний медичний університет імені М. I. Пирогова

\section{CURRENT ISSUES IN TEACHING ONCOLOGY FOR MEDICAL STUDENTS AND FORMATION OF CLINICAL REASONING IN FUTURE DOCTORS}

A. P. Kovalchuk

\author{
Vinnytsya National Medical University by M. I. Pyrohov
}

\begin{abstract}
У зв'язку з невпинним ростом онкопатології на сучасному етапі дуже важливим завданням є якісна підготовка майбутніх лікарів. Вчасна діагностика небезпечних для життя людини захворювань та правильна тактика лікування сприятимуть покращенню прогнозів у таких пацієнтів. У статті представлені основні теоретичні аспекти викладання онкології для студентів медичних вузів та значення цієї дисципліни для формування клінічного мислення, відображені основні методи сучасної діагностики пухлин, фактори канцерогенезу, зокрема впливу професійних шкідливостей на виникнення злоякісних новоутворень, а також розробка профілактичних засобів.
\end{abstract}

Due to the relentless growth of cancer pathology at this stage it is essential to high-quality training of future physicians. Timely diagnosis of life-threatening human diseases and proper treatment strategy will improve forecasts in these patients. This paper presents the main theoretical aspects of teaching oncology for medical students and the importance of this discipline for the formation of clinical thinking, reflects the basic methods of modern diagnostic tumor carcinogenesis factors, including exposure to occupational hazards of malignant tumors, and the development of preventive measures .

Вступ. На Землі щорічно вмирає 2-2,5 млн онкологічних хворих, у 6 млн ця патологія з'являється знову (хворіють 10-12 млн). Злоякісні пухлини є одними з основних причин смерті сучасної людини [15].

За останні два десятиріччя відбулися суттєві зміни в діагностиці та лікувальній практиці хворих на доброякісні та злоякісні новоутворення [2]. Тому не викликає сумніву те, що знання матеріалу такої важливої на сучасному етапі дисципліни, як онкологія, необхідне у роботі лікарів будь-яких спеціальностей з метою покращення лікувально-діагностичної допомоги населенню.

Майбутній лікар повинен отримати фундаментальні знання, необхідні для своєчасної та правильної постановки діагнозу, вибору тактики лікування онкохворих.

Метою нашої роботи було проаналізувати літературні джерела з сучасних питань онкології та розробити нові методологічні підходи до вивчення цієї дисципліни студентами медичних університетів.

Основна частина. Онкологічні захворювання дуже поширені у сучасному світі. Захворюваність на новоутворення серед чоловіків працездатного віку

(c) А. П. Ковальчук призводить до вкорочення життя на 9,5 року, серед жінок - на 8,7. Максимальні втрати років життя пов'язані з виникненням раку легенів, шлунка, молочної залози, шийки матки та гемобластозів [5].

Чималий внесок у статистику онкопатології вносять захворювання, зумовлені професійною діяльністю. Частина з них виникає вже в працездатному віці, але в силу тривалості латентного періоду багато випадків реєструються лише після виходу працівників на пенсію [12].

На частку професійних факторів як причин онкологічної смертності припадає 2-5\% всіх випадків смерті. Внесок професійних впливів у причини смертності від різних локалізацій варіює від 1 \% (передміхурова залоза) і до 25 \% (плевра, носові пазухи та ін.), а в канцерогенних виробництвах - від 2 до $38 \%$. Зростання онкологічної захворюваності та смертності зумовлено численністю контингенту, що має контакт з професійними канцерогенами [12].

Зокрема професійний рак - це злоякісне новоутворення, причиною виникнення якого $€$ фактори виробничого середовища і трудової діяльності. Рак не одинична форма захворювання, а сукупність нозологічних форм, кожна 3 яких характеризується власними 
етіологічними, морфологічними, патофізіологічними та клінічними особливостями. Спільними для них є: прогресуючий ріст пухлинної тканини, структурні відмінності з нормальним ростом (ядерна, клітинна і тканинна атипія, поліморфізм), поширення і розвиток пухлинних клітин (метастазування) у віддалених від первинної пухлини частинах організму за допомогою їх проникнення по кров’ яному і лімфатичному руслу.

Основні характеристики професійного раку:

1) пов'язаний з впливом канцерогенів на виробництві;

2) тривалий латентний період розвитку - в середньому 15-18 років, що ускладнює встановлення зв' язку з професією, особливо в осіб, які залишили канцерогенонебезпечні виробництва;

3) концеепичія дії будь-якої дози канцерогену (як завгодно мала) може викликати ефект (мутацію, ініціювати клітини-мішені та ін.);

4) неоднорідність популяиії, в тому числі і професійних груп, щуодо чутливості до канцерогенного впливу (вікові, статеві, генетично детерміновані відмінності в здатності метаболізувати канцерогени, стан здоров' я, особливості способу життя) [11].

Перший опис професійного раку шкіри у сажотрусів зробив у 1775 році англійський лікар Потт. Через 120 років (у 1895 році) описано рак сечового міхура у робітників анілінофарбової промисловості, на початку XX століття - рак легенів у гірників. Надалі було встановлено випадки розвитку професійного раку від впливу інших хімічних речовин і фізичних факторів [7].

Найбільшу питому вагу в структурі професійних пухлин займає рак шкіри, легенів, верхніх дихальних шляхів і сечового міхура, менший - лейкози та пухлини інших органів [11].

Особливістю професійних новоутворень $є$ те, що вони не мають специфічних клінічних і морфологічних ознак при порівнянні їх з новоутвореннями цих же органів непрофесійного генезу.

Проблема виробничих впливів канцерогенів відображається не тільки на здоров’ї працюючих, а й на здоров її дітей, включаючи і онкологічний ризик. Це стосується впливу на батьків нафтопродуктів, органічних розчинників, електромагнітних полів, нагріваючого мікроклімату, хімічних речовин, нафтопродуктів, високих температур, зварювального аерозолю, іонізуючої радіації, при наявності яких достовірно підвищується ризик розвитку злоякісних захворювань у дітей [8].

Екзогенні та ендогенні причини виникнення онкологічних захворювань охоплюють практично всі можливі чинники - спадковість, харчування, фактори ви- робничого та навколишнього середовища, інфекції, спосіб життя (куріння, зловживання алкоголем), імунологічний статус організму.

Канцерогенними етіологічними факторами на виробництві можуть бути хімічні речовини та аерозолі, віруси, різні види випромінювань, присутні в навколишньому середовищі, або потрапляють 3 продуктами харчування та водою в організм [13].

Зростанню онкологічної захворюваності може сприяти такий фактор трудової діяльності, як психоемоційний стрес [10].

Канцерогенні речовини можуть входити до складу сировини, утворюватися на проміжних стадіях технологічного процесу, утримуватися в кінцевому продукті та надходити в навколишнє середовище у вигляді викидів. Відповідно до Конвенції про безпеку при використанні хімічних речовин на виробництві термін "використання хімічних речовин на виробництві" означає: 1) виробництво; 2) звернення; 3) зберігання; 4) транспортування; 5) видалення та обробку відходів хімічних речовин; 6) викид хімічних речовин у результаті виробничої діяльності; 7) експлуатацію, ремонт і очищення хімічного обладнання та контейнерів [4].

Міжнародне агентство з вивчення раку (МАВР) розробило критерії з оцінки канцерогенної активності хімічних сполук, основані на ступені доведеності канцерогенності того чи іншого з'єднання для людини або тварини. Ця робота триває постійно. За критеріями МАВР виділені 4 групи хімічних речовин, сполук і сумішей, виробничих впливів і процесів за ступенем доведеності канцерогенності для людини:

1. Фактори, щодо яких є переконливі докази канцерогенності їх для людини.

2. Фактори, для яких є майже переконливі докази канцерогенності для людини або за відсутності таких - переконливі докази канцерогенності для тварин. Ця група розділена на 2 підгрупи: підгрупа 2 A ймовірні канцерогени; 2 Б - можливі канцерогени.

3. Хімічні сполуки, їх групи, виробничі процеси або професійні впливи, які не можуть бути класифіковані з точки зору їх канцерогенності для людини.

4. Фактори, вплив яких ймовірно не канцерогенний для людини.

Речовини і продукти з доведеною для людини канцерогенністю: 4-амінобіфеніл - рак сечового міхура; азбести - рак легенів, мезотеліома плеври й очеревини, рак гортані, товстої, прямої кишок; афлатоксини (В 1 а також природна суміш афлатоксинів) - печінка, легені; бензидин - рак сечового міхура; бензол-лейкоз; бенз (а) пірин-рак легенів, шкіри; берилій та його сполуки - рак легенів; бісхлорметиловий i 
хлорметиловий (технічний) ефіри - легені; вінілхлорид - ангіосаркома печінки, рак головного мозку, легенів, лейкоз, лімфома; кадмій та його сполуки-органи дихання і сечовиділення, простата; іприт сірчистийрак легенів; кам'яновугільні і нафтові смоли - рак шкіри, легенів, сечового міхура, шлунка; мінеральні масла (нафтові і сланцеві) неочищені і неповністю очищені - рак шкіри, шлунка; миш'як і його неорганічні сполуки - рак шкіри, легенів; 1-нафтиламін технічний, більше 0,1 \% 2-нафтиламіну - сечовий міхур; 2-нафтиламін - сечовий міхур; нікель, його сполуки і суміші сполук нікелю-рак легенів, носової перегородки; тальк, що містить азбестоподібні волокна, - легені, мезотеліома плеври й очеревини; 2,3,7,8-тетрахлорбензо-пара-діоксин - хрому шестивалентної сполуки - рак легенів; еріоніт - злоякісні новоутворення плеври та очеревини; етилену оксид - пухлини лімфатичної та кровотворної тканини, шлунка [4].

Виробничі процеси і виробництва з доведеною канцерогенною небезпекою для людини: деревообробне та меблеве виробництво з використанням фенолформальдегідних і карбамід-формальдегідних смол у закритих приміщеннях - рак порожнини носа, легенів; мідеплавильне виробництво - рак легенів; виробнича експозиція до радону в умовах гірничодобувної промисловості і роботи в шахтах - рак легенів; виробництво ізопропілового спирту - рак синусів, порожнини носа, гортані; виробництво коксу, переробка кам'яновугільної, нафтової і сланцевих смол - газифікація вугілля - рак легенів, шкіри, лейкоз; виробництво гуми та гумових виробів - рак легенів, шлунково-кишкового тракту, головного мозку, лейкоз і лімфома, рак сечового міхура, шкіра, лімфатичної системи; виробничі процеси, пов'язані з експозицією до аерозолю сильних неорганічних кислот, що містять сірчану кислоту, - рак порожнина носа, гортань, легені [1].

Одним $з$ актуальних завдань медицини на сучасному етапі є об'єктивна оцінка онкологічної захворюваності серед виробничих контингентів і розробка системи профілактичних заходів [10]. Під час практичних занять студенти медичних університетів повинні отримати знання, пов'язані з цим напрямком.

У зв'язку з впровадженням кредитно-модульної системи і скороченням кількості практичних занять та лекцій [6], кафедра онкології дещо змінила методичні підходи до викладання цієї дисципліни для оптимізації навчально-методичного процесу.

3 метою кращого засвоєння студентами матеріалу практичних занять на кафедрі розроблено достат- ню кількість тестів (із бази даних “Крок”), різноманітних ситуаційних задач українською, російською i англійською мовами, при вирішенні яких студенти набувають нових знань $з$ цієї дисципліни, навчаються правильно формулювати клінічні діагнози відповідно до вимог Міжнародної класифікації хвороб (Х перегляд), адаптованої до вітчизняної практичної охорони здоров'я.

Крім того, підготовлені до друку нові навчальнометодичні посібники, що включають основні теоретичні відомості з онкології.

Особливу увагу ми приділяємо правильному формулюванню клінічного мислення. Кожен лікар повинен пам'ятати, що правильна постановка діагнозу залежить від аналізу клінічних симптомів, лабораторних та інструментальних методів дослідження $[2,9,14]$.

У сучасних умовах одним із основних завдань лікаря є вміння діагностувати пухлину на ранній стадії, коли можливе ії радикальне лікування. Для цього не достатньо звичайних фізикальних методів (огляд, пальпація, аускультація), а необхідні сучасні високотехнологічні принципи та методи з застосуванням нових апаратів та приладів. Це підкреслює необхідність пошуку можливостей впровадження нових, більш інформативних методів викладання. Такі проблеми вирішуються за допомогою електронної бази даних, що дозволяє демонструвати наочні матеріали під час практичних занять. До матеріалу презентацій для студентів включена інформація про епідеміологію новоутворень у світі та в Україні, передракові захворювання, гістологічні форми злоякісних пухлин різних локалізацій, сучасна класифікація, скарги, об' єктивні симптоми й спеціальні методи діагностики (термографія, радіонуклідне дослідження, УЗД, КТ, МРТ, ендоскопія, гістологічні дослідження, імуногістохімія тощо) та методи лікування (радикальні, паліативні й симптоматичні операції, променева та хіміотерапія). Такий демонстраційний матеріал компенсує відсутність тематичних хворих. Незважаючи на значні успіхи у розкритті механізмів розвитку онкологічних захворювань, багато проблем залишаються невирішеними. На практичних заняттях слід звернути увагу студентів на морфогенез та патоморфоз пухлин.

Розвиток пухлини - це процес, що складається 3 декількох стадій: ініціації, промоції, прогресії. Ініціація - це процес виникнення первинних мутаційних змін генотипу клітин-мішеней і незворотного переходу цих клітин до трансформаціі. Ініціатор - канцерогенний чинник. Промоція - це процес перетворення ініційованих клітин у трансформовані. Промотор - агент, 
який приводить у трансформований стан тільки ініційовані клітини. Прогресія - процес еволюції деяких незалежних ознак пухлини, пов'язаних з посиленням їі злоякісності. Канцерогенний ризик - це ймовірність значного підвищення частоти виникнення пухлин у людей, що піддаються впливу певних канцерогенних факторів у побуті та/або на виробництві і корелює з індивідуальними особливостями способу життя, ендогенними факторами, забрудненням навколишнього середовища або з деякими професійними шкідливостями [2].

3 сучасної точки зору, рак є генетичним захворюванням (захворювання геному клітини). Одна із сучасних теорій канцерогенезу - теорія онкогенів - виходить 3 того, що всі клітини людини мають у складі своєї ДНК геном онкогенних РНК-вмісних вірусів, що складається з вірогена (формування вірусної частинки) і онкогена (злоякісна трансформація нормальної клітини). Вірусні гени в клітині міцно репресовані спеціальними білками-репресорами. Екзо- і ендогенні канцерогенні фактори - хімічні, фізичні, біологічнісприяють дерепресії (активізації) геному онкорнавірусів, синтезу віріонів, дерепресії оперону онкогена, індукції мутації в клітинних протоонкогенах - ядерних генах (їх активація) статевих (спадковий сімейний рак) або соматичних (неспадковий рак) клітин господаря [15].

Екзогенні причини виникнення канцерогенного ефекту:

1) хімічні речовини різних класів і видів з'єднань деякі метали і металоїди, їх з'єднання, пил органічного та неорганічного складу аморфної, кристалічної та волокнистої структури, кислоти, луги та хімічно нейтральні речовини у вигляді парів, газів і рідини;

2) фізичні фактори - випромінювання і поля - іонізуючі, неіонізуючі (електричні та магнітні), ультрафіолетові;

3) біологічні агенти - віруси, грибки, речовини тваринного і рослинного походження.

Хімічний канцерогенез. Хімічні канцерогени (генотоксичні і негенотоксичні), включаючи гормони, відповідальні за виникнення 80-90 \% усіх злоякісних пухлин людини. Більшість ксенобіотиків, що забруднюють навколишнє середовище, існують у вигляді стабільних сполук, так званих проканцерогенів, які в організмі перетворюються на високореактивні похідні, що володіють загальнотоксичними, канцерогенними та мутагенними властивостями і є безпосередніми канцерогенами. Канцерогенна дія генотоксичних канцерогенів є безпороговою: теоретично достатньо одній молекулі зв'язатися ковалентно з ДНК, щоб виникла пухлина. Ефект негенотоксичних канцерогенів (клітинна проліферація, стрес тощо) відносять до порогового. Незважаючи на панування концепції безпорогового, визнано, що хімічним канцерогенам притаманна залежність доза-час-ефект, що надає більш міцні основи системі гігієнічної профілактики, прагнення максимально знизити канцерогенне навантаження на організм [4].

Вірусний канцерогенез. До числа вірусів, здатних викликати пухлини та індукувати неопластичну трансформацію клітин in vitro, відносяться ДНК-вмісні РНК-вмісні ретровіруси. У їх геномі є спеціальні генионкогени, білковий продукт яких відповідає за інактивацію генів-супресорів і перетворення нормальної клітини в пухлинну. Пухлинні віруси -це один з можливих етіологічних факторів канцерогенезу поряд зі спонтанним й індукованим мутагенезом, викликаним, зокрема, хімічними канцерогенами або радіацією. Хімічні канцерогени, навіть короткоживучі, діють на тканини протягом декількох годин чи десятків хвилин. Латентний період раку при цьому вимірюється десятиліттями [2].

Радіаційний канцерогенез. Особливістю дії радіації при одноразовому опроміненні $є$ надзвичайно короткий час іiї контакту з клітинами-мішенями - $10^{-17}-$ $10^{-18} \mathrm{c}$, а розвиток раку відбувається через роки i навіть десятиліття. Виділяють фізичну $\left(10^{-16}-10^{-12} \mathrm{c}\right)$, хімічну $\left(3^{-10} \mathrm{c}\right)$ і клітинно-тканинну (біологічну) тимчасові дії радіації на живі об'єкти. Радіація викликає неспецифічні ушкодження ДНК у вигляді множинних порушень структури, хромосом-хромосомних і хроматидних аберацій, нових аберацій у нащадків, нестабільності геному у них (випадкові хроматидні та хромосомні зміни). Ініціація канцерогенезу здійснюється, очевидно, в результаті взаємодії радіації з ДНК. Корпускулярна радіація має більш сильну канцерогенну дію, ніж електромагнітна (рентгеноі гамма-випромінювання). Відбувається підсумовування пре- і постанатального ефектів і посилення канцерогенезу при транспланцентарному впливі бластомогенних факторів на плід [2].

Серед причин дитячої смертності пухлини в багатьох країнах світу займають друге місце. Попередній вплив на організм малих доз канцерогенів, що не викликають утворення пухлини, збільшує чутливість до подальшої канцерогенної дії [15].

Незважаючи на те, що людство докладає величезних зусиль, багато питань механізму розвитку пухлин залишаються недостатньо розкритими:

1. Внаслідок тривалого латентного періоду професійне новоутворення маніфестується після виходу осо- 
би онконебезпечної професії на пенсію, у відношенні якого ніяке спеціально організоване медичне спостереження не здійснюється [11].

2. Недостатня інформованість практикуючих лікарів, включаючи онкологів, в питаннях професійних новоутворень, недооблік профмаршруту і контактів 3 канцерогенами в сукупності з відсутністю специфічних клінічних і морфологічних особливостей [5].

3. Як правило, у санітарно-гігієнічній характеристиці робочого місця не відображається наявність канцерогенів [7].

Основними принципами лікування онкопатології є:

1) індивідуальний підхід до кожного пацієнта;

2) комплексний підхід з урахуванням характеру, локалізації, стадії пухлинного процесу, професії, стажу, віку, супутніх захворювань, ускладнень, статі, маси тіла, що включає етіологічне, патогенетичне і симптоматичне лікування, консервативне (хіміо- та променева терапія), хірургічне та комбіноване лікування [2].

Профілактика новоутворень полягає в ідентифікації канцерогенів у виробничому середовищі, гігієнічній оцінці та моніторингу впливу на різних (у тому числі й регламентованих) рівнях відомих для людини канцерогенних факторів, створенні регістрів щодо осіб, зайнятих на канцерогенно-небезпечних виробницт-

\section{Література}

1. Гигиена труда в угольной промышленности / [Б. Е. Алтынбеков, Р. В. Борисенкова, Е. И. Воронцова и др.] // Руководство по гигиене труда. - М. : Медицина, 1987.Т. 2, гл. 8. - С. 36-61.

2. Діагностика та лікування злоякісних новоутворень / [Б. А. Болюх, В. В. Петрушенко, А. А. Ткач та ін.]. - Вінниця : ДП“ДКФ”, 2012.-264 с.

3. Болюх Б. А. // Інноваційні методики викладання в сучасній вищій освіті : навчально-методична конференция : тези. - М., 2011.-С. 14-18.

4. Варивончик Д. В. Санітарно-гігієнічний моніторинг за канцерогенними агентами в Україні: стан та перспективи удосконалення / Д. В. Варивончик // Укр. ж. пробл. мед. праці. -2009. - № 2. - С. 12-20.

5. Проблема профессионального рака на Украине / Л. Н. Горбан, Е. П. Краснюк, А. В. Деметская [и др.] // Тез. докл. 2-го съезда онкологов стран СНГ, 23-26 мая 2000 г. Киев, 2000.

6. Гумінський Ю. Й. Основні положення з організації навчального процесу / Ю. Й. Гумінський, Л. В. Фоміна, А. М. Гулевич. - Вінниця, 2012.

7. Гигиеническая концепция оценки и управления риском профессионального заболевания / В. А. Кагцов, В. Г. Овакимов, Э. И. Денисов, Р. П. Федякина // Гигиена и санитария. - 1993. - № 8. - С. 31-32.

8. Кальянов А. В. О закономерностях и механизме формирования здоровья рабочих / А. В. Кальянов // Вестник гигиены и эпидемиологии. - 1997. - Т. 1, № 2. - С. 89-92. вах, а також виключення канцерогенів з виробничого та навколишнього середовища при розробці нових препаратів і технологій ще до стадії їх практичної апробації та застосування (на основі хімічного аналізу, короткострокових тестів та експериментів за повною програмою досліджень).

Висновки: 1. Засвоєння студентами медичних університетів основних теоретичних аспектів онкології необхідне для правильної постановки клінічних діагнозів 3 використанням найсучасніших методів діагностики, основних принципів їх формулювання.

2. Вивчення студентами на практичних заняттях методів діагностики й лікування онкопатології та профілактичних засобів сприятиме в майбутньому покращенню якості медичної допомоги населенню.

3. Робота викладача вимагає відповідної педагогічної і професійної підготовки, направленої на формування та подальше вдосконалення клінічного мислення, підвищення якості знань вітчизняних й іноземних студентів згідно з вимогами чинних програм i тематичних планів практичних занять з онкології.

Навички, набуті студентами в процесі вивчення онкології, в майбутньому будуть сприяти покращенню якості лікувально-діагностичної роботи молодих спеціалістів.

9. Король Т. М. Вчення про діагноз як важливий розділ біопсійного курсу для формування клінічного мислення у майбутніх лікарів / Т. М. Король // Biomedical and Biosocial Antropology.-2013.-№ 20.-C. 156-159.

10. Кундиев Ю. И. Медицина труда на Украине на пороге 21 века / Ю. И. Кундиев // Международная конференция "Медицина труда в третьем тысячелетии" : тезисы докладов, 23-25 июня 1998 г.-М., 1998.-С. 39.

11. Кундієв Ю. І. Професійний рак: епідеміологія та профілактика : монографія // Ю. І. Кундієв, А. М. Нагорна, Д. В. Варивончик. - К. : Наукова думка, 2008. - 336 с.

12. Кундієв Ю. І. Професійний рак: стан і перспективи вивчення в Україні / Ю. І. Кундієв, Д. В. Варивончик, О. І. Ременник// Онкология. -2010.-Т. 12, №3.-С. 224-228.

13. Лищиков В. А. Профессиональная заболеваемость в Украине (динамика за последние 10 лет, причины формирования и пути сохранения профзаболеваний населения) / В. А. Лищиков, И. П. Лубянова // Гигиена труда.-К., 1999. - Вып. 30.- С. 13-22.

14. Мілерян В. Є. Методичні основи підготовки і проведення навчальних занять у медичних вузах (методичний посібник) / В. Є. Мілерян. -К. : Хрещатик, 2001.-С. 75-76.

15. Чехун В. Ф. Сучасний стан та перспективи фундаментальних досліджень в експериментальній та клінічній онкології / В. Ф. Чехун // Онкология. - 2010. - Т. 12, № 3. C. 219-223. 